\title{
PENGUASAAN INTEGRASI VISUAL-MOTOR KANAK-KANAK PRASEKOLAH DI SK, SJKC DAN SJKT
}

\author{
Visual-Motor Integration Performance of Preschoolers in SK, SJKC and SJKT
}

\author{
Atikah Mohd Tahir ${ }^{1}$, Faridah Yunus ${ }^{2}$ \\ Jabatan Pendidikan \& Kesejahteraan Komuniti, Fakulti Pendidikan \\ Universiti Kebangsaan Malaysia, Selangor, Malaysia \\ atikahbtmohdtahir@gmail.com ${ }^{1}$, faridahyunus@ukm.edu.my ${ }^{2}$
}

\begin{abstract}
ABSTRAK
Integrasi visual-motor (IVM) merupakan kebolehan untuk mengkoordinasi kemahiran persepsi visual dan motor halus. IVM mempunyai hubungan dengan kemahiran asas pembelajaran seperti membaca, menulis dan kemahiran matematik. Tujuan kajian ini adalah untuk meninjau penguasaan IVM kanak-kanak prasekolah di SK, SJKC dan SJKT. Beery VMI-6 versi pendek telah digunakan untuk menaksir penguasaan IVM kanak-kanak prasekolah. Seramai 359 orang kanak-kanak prasekolah telah dipilih secara rawak menggunakan teknik pensampelan rawak kluster dari 20 buah institusi prasekolah KPM. Dapatan kajian menunjukkan terdapat perbezaan yang signifikan antara penguasaan IVM kanak-kanak prasekolah di SK, SJKC dan SJKT. Kanak-kanak prasekolah di SJKC didapati mempunyai penguasaan IVM yang lebih tinggi daripada kanak-kanak prasekolah di SK dan SJKT. Kesimpulannya, kanak-kanak prasekolah dari jenis sekolah yang berbeza turut mempunyai penguasaan IVM yang berbeza. Perbezaan sukatan dan aktiviti pembelajaran dijangka memberi impak kepada penguasaan IVM kanakkanak prasekolah. Kajian lanjutan perlu memberi fokus kepada pengaruh etnik dan budaya terhadap penguasaan IVM kanak-kanak prasekolah.
\end{abstract}

Kata kunci: integrasi visual-motor, persepsi visual, koordinasi motor halus, Beery VMI, kanak-kanak prasekolah

\begin{abstract}
Visual-motor integration (VMI) is the ability to coordinate visual perception and fine motor skills. VMI is associated with many basic learning skills such as reading, writing and mathematics. The aim of this study was to explore the VMI performance of SK, SJKC and SJKT preschoolers. The Beery VMI-6 short version was used to assess the VMI performance of preschoolers in this study. A total of 359 preschoolers were recruited from 20 KPM preschools using the cluster random sampling technique. The result showed significant difference between the VMI performance of SK, SJKC and SJKT preschoolers. SJKC preschoolers performed the highest for VMI compared to SK and SJKT. As a conclusion, preschoolers from different type of schools had different VMI performances. This may be due to different syllabi and learning activities that had affected VMI performances. Future research needs to focus on the influences of ethnicity and culture in the preschoolers' VMI performance.
\end{abstract}

Keywords: visual-motor integration, visual perception, fine motor coordination, Beery VMI, preschoolers

\section{PENGENALAN}

Integrasi visual-motor (IVM) didefinisikan sebagai darjah sejauh mana persepsi visual dan koordinasi motor halus jari tangan dapat berintegrasi dengan baik (Beery \& Beery 2010). IVM merupakan suatu kemahiran di bawah domain perkembangan kognitif dan fizikal. Penguasaan IVM diperlukan oleh kanak-kanak untuk melaksanakan aktiviti dalam kehidupan seharian dengan baik seperti memberus gigi, mengikat tali kasut, membutang dan mengzip pakaian (Oliveira et al., 2016). Secara umumnya, penguasaan IVM kanak-kanak berkembang seiring dengan peningkatan umur (Ercan, Ahmetoglu, \& Aral, 2011). Namun, Tekok-kiliç, Keç, dan 
Can (2010) mendapati bahawa umur empat hingga tujuh tahun merupakan tempoh sensitif dalam perkembangan IVM kanak-kanak. Menurut Berk (2013), ketika tempoh sensitif, perkembangan IVM kanak-kanak lebih terdedah kepada kesan ransangan persekitaran berbanding tempoh umur yang lain. Byers et al. (2016) mendapati penglibatan kanak-kanak dalam aktiviti di prasekolah mempunyai hubungan dengan penguasaan IVM kanak-kanak secara semulajadi. Aktiviti menguli doh, menggunting, mencantum puzzle, membina blok, mewarna, menulis dan melukis di prasekolah secara tidak langsung membantu kanak-kanak prasekolah untuk menguasai IVM secara berperingkat. Melalui penguasaan IVM secara berperingkat, Beery dan Beery (2010) menjangkakan pada usia enam tahun, kanak-kanak prasekolah dapat mengintegrasi kemahiran persepsi visual dengan kemahiran motor halus jari tangan serta menguasai kemahiran menulis dengan lebih kompeten.

\section{KAJIAN LITERATUR}

Pendidikan prasekolah di Malaysia bertujuan menyuburkan potensi kanak-kanak dalam domain perkembangan fizikal, kognitif dan sosioemosi secara holistik. Selain itu, pendidikan prasekolah juga bertujuan menyediakan kanak-kanak dengan kemahiran asas membaca, menulis dan matematik sebelum kanak-kanak mengikuti pembelajaran formal di Tahun 1 . Namun begitu, Pienaar, Barhorst dan Twisk (2013) mendapati kanak-kanak prasekolah sukar untuk menguasai kemahiran asas membaca, menulis dan matematik jika kanak-kanak prasekolah mempunyai masalah dalam penguasaan IVM. Antara ketiga-tiga kemahiran asas iaitu membaca, menulis dan matematik; penguasaan IVM didapati lebih diperlukan oleh kanakkanak prasekolah untuk menguasai kemahiran menulis. Kajian oleh Barnhardt et al. (2005) mendapati kanak-kanak yang mempunyai penguasaan IVM yang rendah sering membuat kesalahan jarak dalam menulis huruf dan perkataan ketika melaksanakan tugasan yang melibatkan kemahiran menulis. Selain itu, penguasaan IVM didapati menjadi peramal kepada kualiti tulisan tangan (Kaiser, Albaret, \& Doudin, 2009) dan kepantasan kanak-kanak untuk menulis (Brown \& Link 2016). Penguasaan IVM juga mempunyai hubungan dengan kebolehan kanak-kanak untuk meniru huruf dengan betul dan boleh dibaca (Lotz, Loxton, \& Naidoo, 2005) serta keupayaan kanak-kanak untuk menulis nama dari memori (Clark \& Luze 2014). 
Penguasaan IVM juga didapati mempunyai hubungan dengan kemahiran membaca kanak-kanak (Pienaar et al. 2013; Sortor \& Kulp 2003). Tore et al. (2016) mendapati penguasaan IVM mempunyai hubungan dengan kebolehan kanak-kanak untuk membaca dengan pantas dan tepat. Kanak-kanak yang mempunyai penguasaan IVM yang tinggi menunjukkan kebolehan membaca secara pantas berbanding kanak-kanak yang mempunyai penguasaan IVM yang rendah. Emam dan Kazem (2014) pula telah mendapati kanak-kanak yang mempunyai ketidakupayaan membaca mempunyai penguasaan IVM yang lebih rendah berbanding kanak-kanak tipikal. Emam dan Kazem berpendapat penaksiran IVM penting untuk dilaksanakan bagi mengdiagnosis kanak-kanak yang didapati mempunyai ciri-ciri ketidakupayaan membaca di peringkat sekolah. Selain daripada kemahiran menulis dan membaca, penguasaan IVM juga didapati mempunyai hubungan dengan kemahiran matematik (Pienaar et al. 2013). Barnhardt et al. (2005) mendapati kanak-kanak yang mempunyai masalah penguasaan IVM lebih banyak membuat kesilapan penjajaran dan penyusunan angka semasa menjawab soalan matematik berbanding kanak-kanak tipikal. Menurut Pieters et al. (2012), tanpa penguasaan IVM yang baik, kanak-kanak sukar untuk meniru dan menulis angka dengan betul sekaligus menjejaskan prestasi kanak-kanak ketika menjawab soalan matematik secara bertulis.

Berdasarkan kepentingan IVM kepada proses pembelajaran kanak-kanak, maka proses menyuburkan penguasaan IVM kanak-kanak prasekolah amat penting untuk dilaksanakan bagi membantu kanak-kanak prasekolah menguasai kemahiran asas membaca, menulis dan matematik dengan lebih baik. Namun begitu dalam konteks tempatan, penguasaan IVM kanakkanak prasekolah kurang diberikan perhatian khususnya dalam bidang kajian pendidikan. Sehingga kini, kajian mengenai penguasaan IVM kanak-kanak di Malaysia hanya dilaksanakan oleh para penyelidik dalam bidang terapi carakerja, optometrik dan pengajian sukan sahaja. Kelompongan dapatan kajian dalam bidang pendidikan mengenai penguasaan IVM kanakkanak prasekolah menyukarkan para pembuat dasar, pendidik awal kanak-kanak dan ibu bapa untuk membuat tindakan lanjut bagi menyuburkan proses perkembangan IVM kanak-kanak prasekolah di peringkat awal. Maka, satu kajian dalam bidang pendidikan perlu dilaksanakan bagi meninjau penguasaan IVM kanak-kanak prasekolah KPM sebelum proses menyuburkan proses perkembangan IVM kanak-kanak prasekolah dapat dirangka. Prasekolah KPM di Malaysia terdiri daripada institusi prasekolah di Sekolah Kebangsaan (SK), Sekolah Jenis Kebangsaan Cina (SJKC) dan Sekolah Jenis Kebangsaan Tamil (SJKT) yang tertabur secara menyeluruh sama ada di kawasan bandar mahupun luar bandar di seluruh negara. Secara umum, tujuan kajian ini dilaksanakan untuk meninjau penguasaan IVM kanak-kanak prasekolah KPM di prasekolah SK, SJKC dan SJKT di negeri Melaka. Secara spesifik, objektif kajian ini adalah: (i) mengenalpasti tahap penguasaan IVM kanak-kanak prasekolah di SK, SJKC dan SJKT; dan (ii) menentukan perbezaan penguasaan IVM kanak-kanak prasekolah di SK, SJKC dan SJKT. 


\section{METODOLOGI KAJIAN}

Kajian ini merupakan sebuah kajian kuantitatif yang menggunakan rekabentuk tinjauan. Populasi kajian ini terdiri daripada 5316 orang kanak-kanak prasekolah KPM di negeri Melaka. Sampel kajian telah dipilih dengan menggunakan teknik pensampelan rawak kluster. Sebanyak 20 buah institusi prasekolah KPM di SK, SJKC dan SJKT telah dipilih secara rawak dari seluruh negeri Melaka. Oleh itu, seramai 359 orang kanak-kanak prasekolah daripada kesemua 20 buah institusi prasekolah KPM di SK, SJKC dan SJKT telah dipilih untuk menjadi sampel kajian. Berdasarkan Jadual Pensampelan Krejcie dan Morgan (1970), pada aras 95\%, saiz sampel kajian ini adalah memadai untuk mewakili populasi kajian. Jadual 1 menunjukkan bilangan sampel kajian berdasarkan jenis sekolah.

Jadual 1: Bilangan sampel kajian berdasarkan jenis sekolah

\begin{tabular}{ccc}
\hline Jenis sekolah & Bilangan sampel & Peratus \\
\hline SK & 125 & 34.8 \\
\hline SJKC & 122 & 34.0 \\
\hline SJKT & 112 & 31.2 \\
\hline Jumlah & 359 & 100.0 \\
\hline
\end{tabular}

Kajian ini menggunakan instrumen Beery VMI-6 untuk menaksir penguasaan IVM kanakkanak prasekolah. Secara literal, Beery VMI-6 adalah singkatan kepada The Beery-Buktenica Developmental Test Of Visual-Motor Integration edisi keenam. Beery VMI-6 merupakan instrumen penaksiran standard yang mempunyai psikometrik kesahan dan kebolehpercayaan yang tinggi. Beery dan Beery (2010) melaporkan bahawa ketekalan dalaman Beery VMI-6 adalah 0.89, manakala kebolehpercayaan uji dan uji semula antara ujian I dan ujian II dengan selang masa 14 hari adalah 0.88. Kajian ini menggunakan Beery VMI-6 versi pendek yang terdiri daripada 21 item geometri yang digunakan untuk menaksir perkembangan IVM kanakkanak yang berumur dua hingga tujuh tahun sahaja. Susunan item geometri di dalam Beery VMI-6 adalah berdasarkan perkembangan IVM kanak-kanak iaitu dari tahap yang mudah kepada tahap yang lebih sukar.

Beery VMI-6 telah ditadbir ke atas sampel kajian dengan menggunakan kaedah saringan secara berkumpulan dengan bilangan maksimum kanak-kanak prasekolah adalah seramai 25 orang manakala bilangan pentadbir ujian adalah sekurang-kurangnya dua orang dalam suatu masa. Beery VMI-6 telah ditadbir di dalam kelas prasekolah dengan bantuan guru prasekolah dan pembantu pengurusan murid. Sampel kajian perlu meniru 21 item geometri di dalam Beery VMI-6 mengikut urutan. Sampel kajian tidak dibenarkan untuk menggunakan pemadam dan pembaris semasa meniru item geometri di dalam Beery VMI-6. Larangan penggunaan pemadam dan pembaris dimaklumkan kepada sampel kajian sebelum instrumen Beery VMI-6 ditadbir. Secara purata, tempoh pentadbiran Beery VMI-6 mengambil masa 10 hingga 15 minit apabila ditadbir secara berkumpulan. Instrumen Beery VMI-6 dikutip apabila sampel kajian telah siap meniru kesemua 21 item geometri dengan lengkap. Analisis deskriptif frekuensi dan peratusan telah diguna untuk menghuraikan tahap penguasaan IVM kanak-kanak 
prasekolah di SK, SJKC dan SJKT. Analisis inferensi ANOVA pula diguna untuk menentukan perbezaan penguasaan IVM antara kanak-kanak prasekolah di SK, SJKC dan SJKT.

\section{DAPATAN KAJIAN}

\section{Tahap Penguasaan IVM Kanak-Kanak Prasekolah di SK, SJKC dan SJKT}

Tahap penguasaan IVM kanak-kanak prasekolah dinilai berpandukan kepada Jadual 2 iaitu Jadual Interpretasi Skor Standard Beery VMI-6 yang telah dikemukakan oleh Beery dan Beery (2010). Jadual 3 menunjukkan bilangan dan peratusan tahap penguasaan IVM kanak-kanak prasekolah di SK, SJKC dan SJKT. Peratusan tahap penguasaan IVM kanak-kanak prasekolah di SK, SJKC dan SJKT telah diterjemahkan dalam bentuk grafik sebagaimana dalam Rajah 1. Secara majoriti, tahap penguasaan IVM kanak-kanak di prasekolah SK, SJKC dan SJKT berada pada tahap purata. Namun, kanak-kanak di prasekolah SJKC mencatat peratusan tertinggi bagi tahap penguasaan IVM atas purata, tinggi dan sangat tinggi berbanding kanakkanak prasekolah di SK dan SJKT. Tiada kanak-kanak prasekolah di SK dan SJKT yang mempunyai tahap penguasaan IVM sangat tinggi.

Jadual 2: Jadual Interpretasi Skor Standard Beery VMI-6

\begin{tabular}{cc}
\hline Skor standard IVM & Interpretasi tahap pengusaaan IVM \\
\hline$<129$ & Sangat tinggi \\
$120-129$ & Tinggi \\
$110-119$ & Atas purata \\
$90-109$ & Purata \\
$80-89$ & Bawah purata \\
$70-79$ & Rendah \\
$>70$ & Sangat rendah \\
\hline
\end{tabular}


Jadual 3: Tahap penguasaan IVM kanak-kanak prasekolah di SK, SJKC dan SJKT

\begin{tabular}{lcccccc}
\hline \multicolumn{1}{c}{ Tahap } & \multicolumn{2}{c}{ SK } & \multicolumn{2}{c}{ SJKC } \\
$n=122$ & \multicolumn{3}{c}{$\begin{array}{c}\text { SJKT } \\
\text { Penguasaan IVM }\end{array}$} & \multicolumn{1}{c}{$n=112$} \\
\cline { 2 - 7 } & Bilangan & $\%$ & Bilangan & $\%$ & Bilangan & $\%$ \\
\hline Sangat rendah & 0 & 0.0 & 0 & 0.0 & 0 & 0.0 \\
Rendah & 0 & 0.0 & 0 & 0.0 & 1 & 0.9 \\
Bawah purata & 3 & 2.4 & 4 & 3.3 & 3 & 2.7 \\
Purata & 104 & 83.2 & 62 & 50.8 & 92 & 82.1 \\
Atas purata & 15 & 12.0 & 43 & 35.2 & 15 & 13.4 \\
Tinggi & 3 & 2.4 & 12 & 9.8 & 1 & 0.9 \\
Sangat tinggi & 0 & 0.0 & 1 & 0.9 & 0 & 0.0 \\
\hline
\end{tabular}

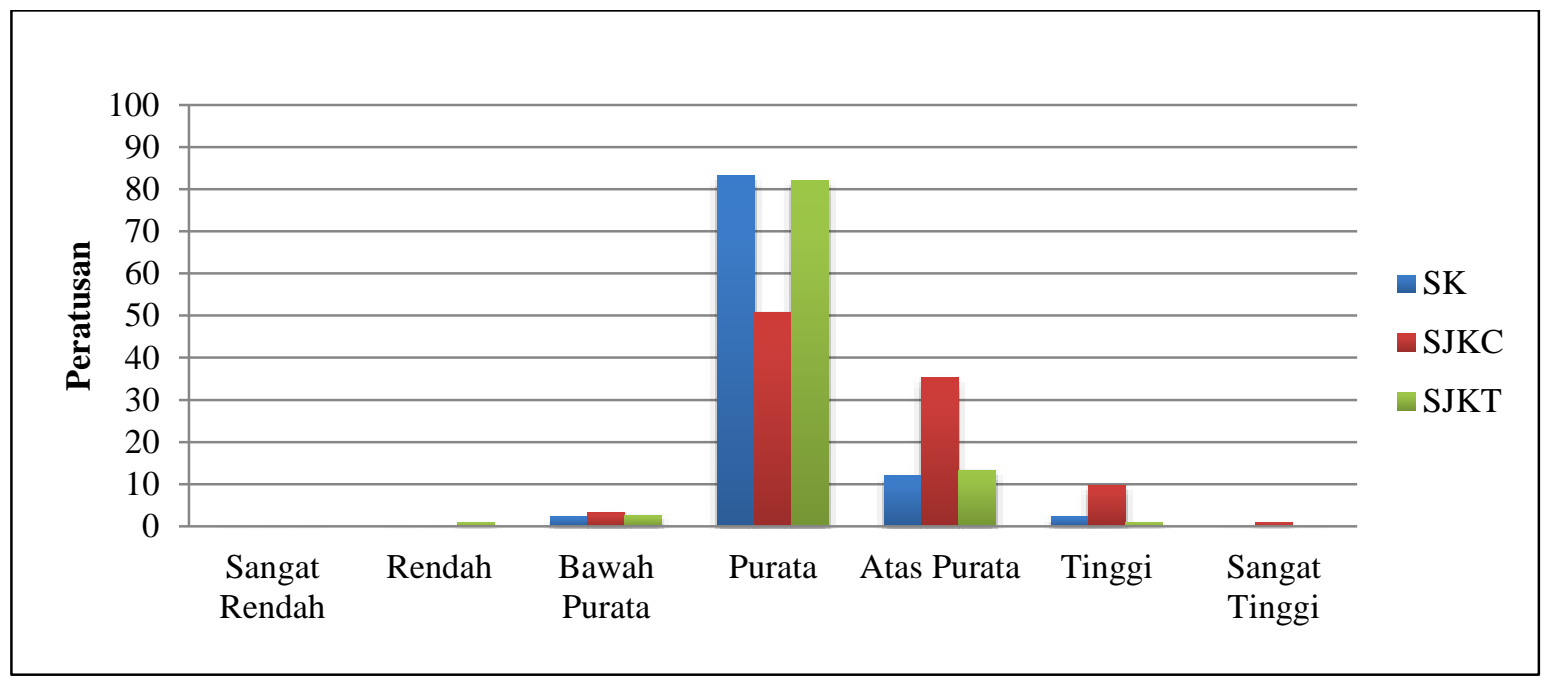

Rajah 1: Peratusan tahap penguasaan IVM kanak-kanak prasekolah di SK, SJKC dan SJKT

\section{Perbezaan Penguasaan IVM antara Kanak-kanak Prasekolah di SK, SJKC dan SJKT}

Rajah 2 merupakan carta bar yang menunjukkan min skor standard IVM kanak-kanak prasekolah di SK, SJKC dan SJKT. Kanak-kanak prasekolah di SJKC (M = 107.52, SP = 9.521) mempunyai min skor standard IVM yang lebih tinggi daripada min skor standard IVM kanakkanak di prasekolah SK $(\mathrm{M}=102.83, \mathrm{SP}=7.459)$ dan SJKT $(\mathrm{M}=101.58, \mathrm{SP}=7.821)$. Ujian ANOVA satu hala telah dilaksanakan untuk menentukan perbezaan penguasaan IVM antara kanak-kanak prasekolah di SK, SJKC dan SJKT. Keputusan ujian ANOVA satu hala dalam Jadual 4 menunjukkan penguasaan IVM antara kanak-kanak prasekolah di SK, SJKC dan SJKT berbeza secara signifikan dengan nilai $F(2,356)=16.902, p<0.05$ dan saiz kesan $\eta^{2}=0.08$. Saiz kesan $\eta^{2}=0.08$ yang sederhana menunjukkan sebanyak $8 \%$ nisbah varians dalam skor standard IVM kanak-kanak prasekolah dijelaskan oleh jenis sekolah. 


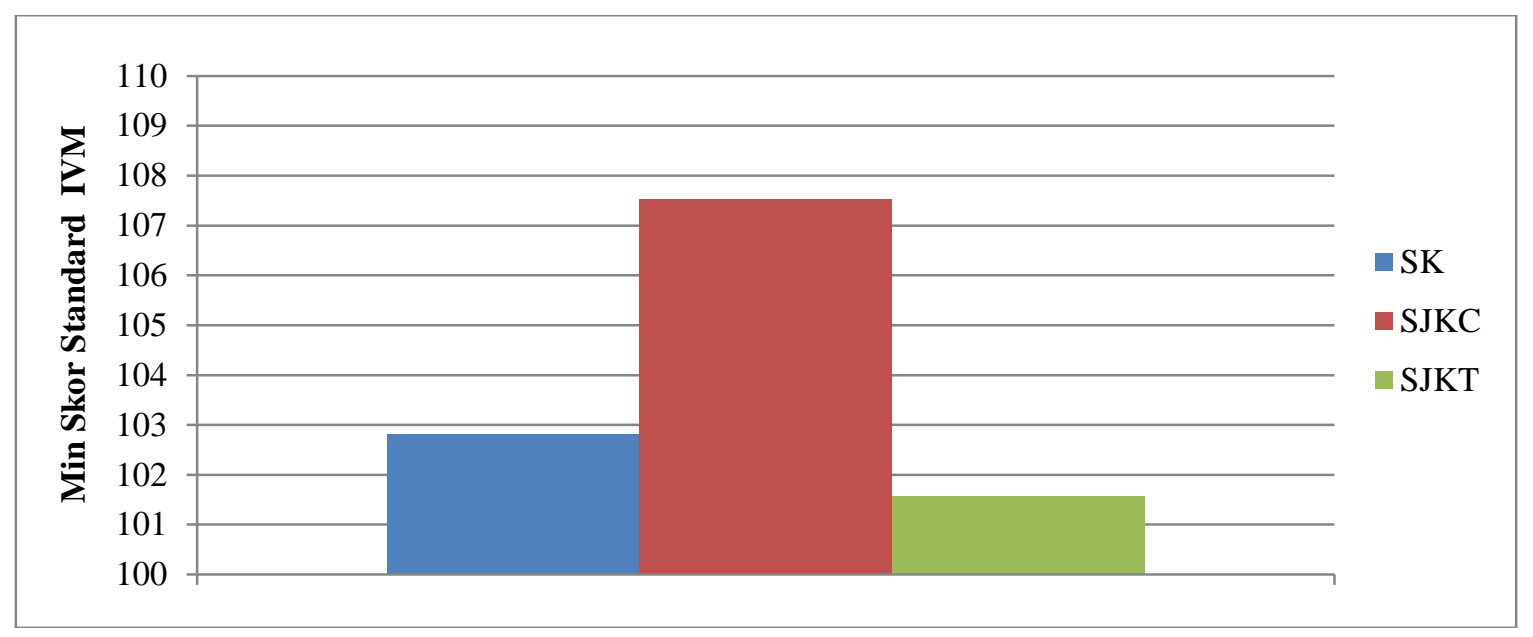

Rajah 2: Min skor standard IVM kanak-kanak prasekolah di SK, SJKC dan SJKT

Jadual 4: Ujian ANOVA satu hala untuk menentukan perbezaan penguasaan IVM kanak-kanak prasekolah di SK, SJKC dan SJKT

\begin{tabular}{lcccccc}
\hline Jenis Prasekolah & $\begin{array}{c}\text { Jumlah Kuasa } \\
\text { Dua }\end{array}$ & df & Min Kuasa Dua & F & Sig. & $\eta^{2}$ \\
& 2341.354 & 2 & 1170.677 & 16.902 & 0.000 & 0.08 \\
Antara Kumpulan & 24657.175 & 356 & 69.262 & & & \\
Dalam Kumpulan & 26998.529 & 358 & & & & \\
Jumlah & & & & & & \\
\hline
\end{tabular}

Bagi mengetahui min skor standard IVM kumpulan yang menyebabkan berlakunya perbezaan yang signifikan, maka ujian Tukey HSD telah dilaksanakan. Keputusan ujian Tukey HSD dalam Jadual 5 menunjukkan hanya min skor standard IVM kanak-kanak prasekolah di SJKC berbeza secara signifikan dengan min skor standard IVM kanak-kanak prasekolah di SK dan SJKT. Sebaliknya, min skor standard IVM kanak-kanak prasekolah di SK tidak berbeza secara signifikan dengan min skor standard IVM kanak-kanak prasekolah di SJKT. Dapatan ini menunjukkan bahawa kanak-kanak prasekolah di SJKC mempunyai penguasaan IVM yang berbeza dengan penguasaan IVM kanak-kanak prasekolah di SK dan SJKT. Manakala, kanakkanak prasekolah di SK dan SJKT mempunyai penguasaan IVM pada tahap yang sama. Dapatan kajian secara keseluruhan menunjukkan bahawa kanak-kanak prasekolah di SJKC mempunyai penguasaan IVM yang lebih tinggi daripada kanak-kanak prasekolah di SK dan SJKT. 
Jadual 5: Ujian Tukey HSD ke atas min skor standard IVM kanak-kanak prasekolah di SK, SJKC dan SJKT

\begin{tabular}{|c|c|c|c|c|}
\hline $\begin{array}{l}\text { Prasekolah } \\
\text { (I) }\end{array}$ & $\begin{array}{c}\text { Prasekolah } \\
\text { (J) }\end{array}$ & $\begin{array}{l}\text { Perbezaan Min } \\
\qquad(\mathrm{I}-\mathrm{J})\end{array}$ & Ralat Piawai & Sig. \\
\hline \multirow[t]{2}{*}{ SK } & SJKC & $-4.693^{*}$ & 1.059 & 0.000 \\
\hline & SJKT & 1.252 & 1.083 & 0.480 \\
\hline \multirow[t]{2}{*}{ SJKC } & SK & $-4.693^{*}$ & 1.059 & 0.000 \\
\hline & SJKT & $5.944^{*}$ & 1.089 & 0.000 \\
\hline \multirow[t]{2}{*}{ SJKT } & SK & -1.252 & 1.083 & 0.480 \\
\hline & SJKC & $-5.944^{*}$ & 1.089 & 0.000 \\
\hline
\end{tabular}

\section{PERBINCANGAN KAJIAN}

Secara keseluruhan, dapatan kajian ini menunjukkan kanak-kanak prasekolah di SK, SJKC dan SJKT mempunyai penguasaan IVM yang berbeza. Kanak-kanak prasekolah di SJKC mempunyai penguasaan IVM yang lebih tinggi daripada kanak-kanak prasekolah di SK dan SJKT. Secara umumnya, kesemua institusi prasekolah KPM sama ada di SK, SJKC mahupun SJKT menggunakan kurikulum yang sama iaitu Kurikulum Standard Prasekolah Kebangsaan (KSPK). Namun, perbezaan sukatan bahasa pengantar dalam Tunjang Komunikasi turut membezakan aktiviti pembelajaran antara kanak-kanak prasekolah di SK, SJKC dan SJKT dan secara tidak langsung mempengaruhi perkembangan IVM mereka. KSPK telah menetapkan Bahasa Melayu sebagai bahasa pengantar di prasekolah SK; Bahasa Mandarin sebagai bahasa pengantar di prasekolah SJKC; manakala Bahasa Tamil sebagai bahasa pengantar di prasekolah SJKT. Berdasarkan sukatan KSPK, kanak-kanak prasekolah di SK, SJKC dan SJKT diberi pendedahan untuk menguasai kemahiran mendengar, bertutur, membaca dan menulis dalam bahasa pengantar yang telah ditetapkan di institusi prasekolah masing-masing. Proses kanakkanak prasekolah di SK, SJKC dan SJKT mengecam, membaca dan menulis abjad dalam mana-mana bahasa sama ada dalam Bahasa Melayu, Bahasa Mandarin mahupun Bahasa Tamil dapat membantu menyuburkan penguasaan IVM kanak-kanak secara tidak langsung.

Namun begitu, proses pembelajaran Bahasa Mandarin dan tulisan Cina lebih menuntut penguasaan IVM yang tinggi (Chung, Lam, \& Cheung, 2017) dalam kalangan kanak-kanak prasekolah di SJKC. Tulisan Cina terdiri daripada ribuan aksara kompleks dan bersifat logografik. Secara purata, setiap aksara tulisan Cina mempunyai 6 hingga 13 strok garisan (Anderson et al., 2013). Bagi membezakan setiap aksara ini dengan baik, kanak-kanak prasekolah di SJKC perlu mengecam dan mengingat setiap bentuk aksara sebelum menguasai literasi membaca dan menulis tulisan Cina. Aksara tulisan Cina berbentuk geometri dan terdiri daripada pelbagai strok garisan melintang, menegak, melengkung dan sendeng yang lebih kompleks berbanding strok abjad tulisan lain (Tse, Siu, \& Li-Tsang, 2017) seperti Rumi, Jawi mahupun Tamil. Oleh itu, kanak-kanak prasekolah di SJKC perlu mengintegrasi kemahiran persepsi visual dengan koordinasi motor halus jari tangan dengan lebih baik ketika menulis tulisan Cina. Latih tubi meniru aksara tulisan Cina membantu kanak-kanak prasekolah untuk menguasai kemahiran menulis tulisan Cina dengan lebih baik (Wang, Mcbride, \& Farver, 2017). Dapatan kajian silang-budaya oleh Cui et al. (2012), Lim et al. (2015) dan Ng et al. (2015) mendapati latih tubi tulisan Cina telah membantu meningkatkan penguasaan IVM kanak-kanak yang berumur tiga hingga enam tahun di China, Singapura dan Hong Kong berbanding kanak-kanak yang tidak mempelajari tulisan Cina. Oleh itu, peluang mempelajari 
tulisan Cina yang lebih kompleks menjadi faktor yang menyebabkan penguasaan IVM kanakkanak prasekolah di SJKC mengatasi penguasaan IVM kanak-kanak prasekolah di SK dan SJKT yang tidak berpeluang mempelajari tulisan Cina; di mana mereka hanya terdedah kepada pembelajaran tulisan Rumi dan Tamil sahaja.

\section{IMPLIKASI KAJIAN}

Penggunaan bahasa pengantar yang berbeza dalam aktiviti pembelajaran di SK, SJKC dan SJKT sebagaimana yang telah ditetapkan dalam KSPK telah memberi impak kepada penguasaan IVM kanak-kanak prasekolah berdasarkan jenis sekolah. Secara umumnya, bahasa merupakan komponen komunikasi utama dalam sesuatu kelompok etnik. Setiap etnik mempunyai bahasa ibunda yang berbeza antara satu dengan lain. Dalam konteks sosiobudaya pendidikan di Malaysia, secara majoriti enrolmen prasekolah di SK terdiri daripada kanakkanak etnik Melayu; prasekolah di SJKC terdiri daripada kanak-kanak etnik Cina; manakala, prasekolah di SJKT terdiri daripada kanak-kanak etnik India. Selain dari perbezaan konteks sukatan dalam kurikulum, budaya dan adat resam yang diamalkan oleh kelompok etnik Melayu, Cina dan India juga dijangka turut mempengaruhi perkembangan IVM kanak-kanak prasekolah. Implikasi daripada kajian ini, maka kajian silang-budaya yang memfokuskan kepada penguasaan IVM kanak-kanak prasekolah berdasarkan etnik perlu dilaksanakan sebagai kajian lanjutan dalam memahami perkembangan IVM kanak-kanak prasekolah dengan lebih komprehensif.

\section{KESIMPULAN}

Secara majoriti, penguasaan IVM kanak-kanak prasekolah di SK, SJKC dan SJKT berada di tahap purata, atas purata dan tinggi iaitu tahap penguasaan IVM yang memuaskan bagi kanakkanak dalam lingkungan umur lima hingga enam tahun. Namun, penguasaan IVM kanak-kanak prasekolah didapati berbeza berdasarkan jenis sekolah. Kanak-kanak prasekolah di SJKC didapati mempunyai penguasaan IVM yang lebih tinggi daripada penguasaan IVM kanakkanak prasekolah di SK dan SJKT. Peluang pembelajaran Bahasa Mandarin dan tulisan Cina yang berbentuk lebih kompleks berbanding tulisan Rumi dan Tamil memberi impak yang baik dalam menyuburkan penguasaan IVM kanak-kanak di prasekolah SJKC. Walaupun Beery dan Beery (2010) menyatakan bahawa penguasaan IVM kanak-kanak bersifat universal iaitu hanya berkembang berdasarkan faktor kematangan; namun, dapatan kajian ini jelas menunjukkan faktor persekitaran iaitu perbezaan sukatan kurikulum antara jenis sekolah menyebabkan penguasaan IVM kanak-kanak prasekolah berbeza pada peringkat umur yang sama. 


\section{RUJUKAN}

Abou-El-Saad, T., Afsah, O., Baz, H., \& Shaaban, W. (2017). The relationship between visual - motor integration and handwriting skills in Arabic-speaking Egyptian children at the age of $4-6$ years. The Egyptian Journal of Otolaryngology, 33(4), 663-669. https://doi.org/10.4103/ejo.ejo

Anderson, R. C., Ku, Y.-M., Li, W., Chen, X., Wu, X., \& Shu, H. (2013). Learning to see the patterns in Chinese characters. Scientific Studies of Reading, 17(1), 41-56. https://doi.org/10.1080/10888438.2012.689789

Barnhardt, C., Borsting, E., Deland, P., Pham, N., \& Vu, T. (2005). Relationship between visual - motor integration and spatial organization of written language and math. Optometry and Vision Science, 82(2), $138-143$.

Beery, K. E., \& Beery, N. A. (2010). The Beery - Buktenica Developmental Test of Visual Motor Integration: administration, scoring and teaching manual (Edisi ke-6). Blomington, MN: Pearson.

Berk, L. E. (2013). Child development (Edisi ke-9). New Jersey: Pearson Education, Inc.

Brown, T., \& Link, J. (2016). The association between measures of visual perception, visual-motor integration, and in-hand manipulation skills of school-age children and their manuscript handwriting speed. British Journal of Occupational Therapy, 79(3), 163-171. https://doi.org/10.1177/0308022615600179

Byers, A. I., Cameron, C. E., Ko, M., LoCasale-Crouch, J., \& Grissmer, D. W. (2016). What preschool classroom experiences are associated with whether children improve in visuomotor integration? Early Education and Development, 27(7), 976-1003. https://doi.org/10.1080/10409289.2016.1175243

Chung, K. K. H., Lam, C. B., \& Cheung, K. C. (2017). Visuomotor integration and executive functioning are uniquely linked to Chinese word reading and writing in kindergarten children. Reading and Writing, 1-17. https://doi.org/10.1007/s11145-017-9779-4

Clark, G. F., \& Luze, G. (2014). Predicting handwriting performance in kindergarteners using reading, fine-motor, and visual-motor measures. Journal of Occupational Therapy, Schools, \& Early Intervention, 7(1), 29-44. https://doi.org/10.1080/19411243.2014.898470

Cui, Y., Zhu, Y., Laukkanen, H., \& Rabin, J. (2012). Evaluation of visual - motor integration skills in preschool and elementary school - aged Chinese children. Journal of Behavioral Optometry, 23(5), 123-128.

Emam, M., \& Kazem, A. (2014). Visual - motor integration in children with and without reading disabilities in Oman. Social and Behavioral Sciences, 112, 548-556. https://doi.org/10.1016/j.sbspro.2014.01.1201

Ercan, Z. G., Ahmetoglu, E., \& Aral, N. (2011). Investigating the visual-motor integration skills of 60-72 month children from high and low socio- economic status as regard age factor. International Education Studies, 4(3), 100-104. https://doi.org/10.5539/ies.v4n3p100

Gardiner, A. K., Bjorklund, D. F., Greif, M. L., \& Gray, S. K. (2012). Choosing and using tools: Prior experience and task difficulty influence preschoolers' tool-use strategies. Cognitive Development, 27(3), $240-254$. https://doi.org/10.1016/j.cogdev.2012.05.001

Gascoyne, S., \& Raban, B. (2012). Sensory play. Australia: Teaching Solutions.

Kahrs, B. A., \& Lockman, J. J. (2014). Tool using. Child Development Perspectives, 8(4), 231-236. https://doi.org/10.1111/cdep.12087

Kaiser, M. L., Albaret, J. M., \& Doudin, P. A. (2009). Relationship between visual - motor integration, eye - hand coordination and quality of handwriting. Journal of Occupational Therapy, Schools and Early Intervention, 2(2), 87-95.

Krejcie, R. V, \& Morgan, D. W. (1970). Determining sample size for research activities. Educational and Psychological Measurement, 38(1), 607-610.

Lim, C. Y., Tan, P. C., Koh, C., Koh, E., Guo, H., Yusoff, N. D.,Tan, T. (2015). Beery-Buktenica Developmental Test of Visual-Motor Integration (Beery-VMI): Lessons from exploration of cultural variations in VisualMotor Integration Performance of preschoolers. Child: Care, Health and Development, 41(2), 213-221. https://doi.org/10.1111/cch.12190

Lotz, L., Loxton, H., \& Naidoo, A. V. (2005). Visual-motor integration functioning in a South African middle childhood sample. Journal of Child \& Adolescent Mental Health, 17(2), 63-67. https://doi.org/10.2989/17280580509486602

Ng, M., Chui, M., Lin, L., Fong, A., \& Chan, D. (2015). Perfomance of the visual - motor integration of preschool children in Hong Kong. Hong Kong Journal of Occupational Therapy, 25, 7-14.

Oliveira, A. L. S. de, Kaiser, V., Azambuja, T. de O., Mallmann, L. U., Lukrafka, J. L., \& Reppold, C. T. (2016). Visual - motor maturity and executive functions in school children. Paidéia (Ribeirão Preto), 26(64), 215223. https://doi.org/10.1590/1982-43272664201609

Pienaar, A. E., Barhorst, R., \& Twisk, J. W. R. (2013). Child : relationships between academic performance, SES school type and perceptual - motor skills in first grade South African learners: NW-CHILD study. Child: Care, Health and Development, 40(3), 370-378. https://doi.org/10.1111/cch.12059

Pieters, S., Desoete, A., Roeyers, H., Vanderswalmen, R., \& Van Waelvelde, H. (2012). Behind mathematical 
learning disabilities: what about visual perception and motor skills? Learning and Individual Differences, 22, 498-504. https://doi.org/10.1016/j.lindif.2012.03.014

Sortor, J. M., \& Kulp, M. T. (2003). Are the results of the Beery - Buktenica Developmental Test of Visual Motor Integration and its subtests related to achievement test. Optometry and Vision Science, 80(11), 758763.

Tekok-kiliç, A., Keç, B. E. Ş. İ., \& Can, H. (2010). Evaluation of visual - motor integration functions in children between 6 - 15 years of age. Turkish Journal of Psychiatry, 7-12. https://doi.org/10.5080/u5974

Tore, P. A. Di, Raiola, G., Altavilla, G., Gervilli, Gm. G., Pignato, S., \& Lipoma, M. (2016). Visual motor skills and reading fluency: A correlational study. Journal of Human Sport and Exercise, 11(Proc1), S233-S238. https://doi.org/10.14198/jhse.2016.11.Proc1.14

Tse, L. F. L., Siu, A. M. H., \& Li-Tsang, C. W. P. (2017). Performance on the Developmental Test of VisualMotor Integration and its supplementary tests: Comparing Chinese and U.S. kindergarten children. Journal of Occupational Therapy, Schools, and Early Intervention, 0(0), 1-12. https://doi.org/10.1080/19411243.2017.1335263

Wang, Y., Mcbride, C., \& Farver, J. A. M. (2017). Becoming literate in Chinese : A comparison of native-speaking and non-native-speaking children. Journal of Research in Reading, O(0), 1-14. https://doi.org/10.1111/1467-9817.12122 